\title{
Review: infliximab increases response and remission rates in fistulising or treatment-resistant Crohn's disease
}

\author{
Marshall JK, Blackhouse G, Goeree R, et al. Infliximab for the treatment of Crohn's disease: a systematic review and \\ cost-utility analysis. Technology report no. 24. Ottawa: Canadian Coordinating Office for Health Technology Assessment \\ (CCOHTA); 2002. http://www.ccohta.ca.
}

\section{QUESTION: In patients with fistulising or treatment-resistant Crohn's disease, is infliximab safe and effective?}

\section{Data sources}

Studies were identified by searching Medline, EMBASE/ Excerpta Medica, Current Contents, CINAHL, HealthSTAR, TOXLINE, the Cochrane Library, Drug Info Full Text, Pharmaceutical \& Health Care Industry News, PharmaProjects, and Pharmaceutical News Index (1990 to May 2001). Scientific meeting abstracts were searched; major clinical gastroenterology journals were hand searched (to August 2001); and authors, government agencies, and pharmaceutical companies were contacted.

\section{Study selection}

2 reviewers independently selected English-language randomised controlled trials (RCTs) that reported clinical end points for infliximab treatment in adults with fistulising or treatment-resistant Crohn's disease.

\section{Data extraction}

2 independent reviewers extracted data on study centres, source of funding, patients, treatment regimens, quality of study methods, and outcomes (response, remission, and fistula closure).

\section{Main results}

4 RCTs met the selection criteria. Fistulising Crohn's disease: 1 RCT $(\mathrm{n}=94)$ showed that more patients in the infliximab groups than in the placebo group had $\geq 50 \%$ closure. Treatment-resistant Crohn's disease: RCTs of treatment-resistant Crohn's disease were too heterogeneous to be combined. The table shows the 4 week and 12 week results for 1 RCT $(n=108)$; in responders, re-infusions of $10 \mathrm{mg}$ infliximab at 8 week intervals led to more remissions $(44 \% v 20 \%, \mathrm{p}=0.013)$ at 44 weeks than did placebo, but the difference in response rate was not statistically significant $(62 \% v 37 \%, \mathrm{p}=0.16)$. The interim 30 week results for 1 RCT $(n=335)$ still in progress showed a benefit for maintenance $5 \mathrm{mg}$ or 10 $\mathrm{mg}$ infliximab. Data from controlled clinical trials showed that serious adverse events occurred in $13 \%$ of patients treated with infliximab and $4 \%$ of patients treated with placebo.

\section{Conclusion}

In patients with fistulising or treatment-resistant Crohn's disease, infliximab increases remission and response rates.

\section{COMMENTARY}

Marshall et al have systematically reviewed the new, interesting topic of treating Crohn's disease with infliximab (a chimeric human-murine monoclonal antibody against the pro-inflammatory cytokine tumor-necrosis factor- $\alpha$ ) and the economic effect of this treatment. The percentage of improvement in patients who received infliximab in all of the studies is impressive, and no doubts exist about its effectiveness in either fistulising or refractory disease. A recent trial by Hanauer $e t a^{1}$ also encourages use of this drug for inducing and maintaining clinical remission in patients with Crohn's disease. The high cost of the treatment might be balanced, at least in part, by a substantial improvement in the quality of life of the patients.

The trials on infliximab suggest that large, serious, and rarely life-threatening side effects, such as acute infusion reactions, human antichimeric antibodies, autoimmune disorders, malignancy, and infection (ie, tuberculosis and intestinal strictures), may result from this treatment. A causal association for some of these side effects is not established yet, but no doubt exists that this potent drug must be managed with great care. The long term follow up will help us to understand better the potential and proper use of this new agent. In the meantime, treatment with infliximab should be offered to a select subgroup of patients with Crohn's disease in whom the need of more effective treatment for severe, persevering, and life limiting symptoms is balanced with the risk for potentially serious side effects.

Andrea Belluzzi, MD S. Orsola Hospital, Bologna, Italy

1 Hanauer SB, Feagan BG, Lichtenstein GR, et al, for the ACCENT I Study Group. Maintenance infliximab for Crohn's disease: the ACCENT I randomised trial. Lancet 2002;359:1541-49.

Infliximab (inflix) for Crohn's disease $(C D)^{*}$

\begin{tabular}{|c|c|c|c|c|c|c|c|}
\hline Patient group & Outcomes & $\begin{array}{l}\text { Number of } \\
\text { patients }\end{array}$ & Dose & Inflix & Placebo & $\mathrm{RBI}(95 \% \mathrm{Cl})$ & NNT (CI) \\
\hline Fistulising CD & $\geq 50 \%$ closure at 18 weeks & 94 & $5 \mathrm{mg}, 10 \mathrm{mg}$ & $62 \%$ & $26 \%$ & $140 \%$ (37 to 363$)$ & 3 (2 to 7 ) \\
\hline Treatment- & Response at 4 weeks & 108 & $5 \mathrm{mg}, 10 \mathrm{mg}, 20 \mathrm{mg}$ & $65 \%$ & $16 \%$ & $307 \%$ (84 to 928$)$ & $3(2$ to 4$)$ \\
\hline \multirow[t]{5}{*}{ resistant $\mathrm{CD}$} & Response at 12 weeks & 108 & $5 \mathrm{mg}, 10 \mathrm{mg}, 20 \mathrm{mg}$ & $41 \%$ & $12 \%$ & $241 \%$ (31 to 908$)$ & $3(2$ to 12$)$ \\
\hline & Response at 12 weeks & 108 & $5 \mathrm{mg}, 10 \mathrm{mg}, 20 \mathrm{mg}$ & $24 \%$ & $8.0 \%$ & $201 \%(-10$ to 10$)$ & Not significant \\
\hline & & & & $\begin{array}{l}\text { Repeat } \\
\text { doses }\end{array}$ & Single dose & & \\
\hline & Response at 30 weeks $\dagger$ & 335 & $5 \mathrm{mg}, 10 \mathrm{mg} \mathrm{v} 5 \mathrm{mg}$ & $55 \%$ & $27 \%$ & $102 \%$ (48 to 183$)$ & $4(3$ to 6$)$ \\
\hline & Response at 30 weeks $\dagger$ & 335 & $5 \mathrm{mg}, 10 \mathrm{mg} \mathrm{v} 5 \mathrm{mg}$ & $42 \%$ & $21 \%$ & $100 \%$ (37 to 199$)$ & $5(4$ to 10$)$ \\
\hline
\end{tabular}

*Abbreviations defined in glossary; RBI, NNT, and $\mathrm{Cl}$ calculated from data in article.

tInterim data reported from a 102-week ongoing trial of maintenance infliximab. 